\title{
Public-Private Wage Differentials and the Quality of Government Workers in the Philippines
}

Max Planck Institute for Tax Law and Public Finance

Working Paper 2015 - 06

June 2015

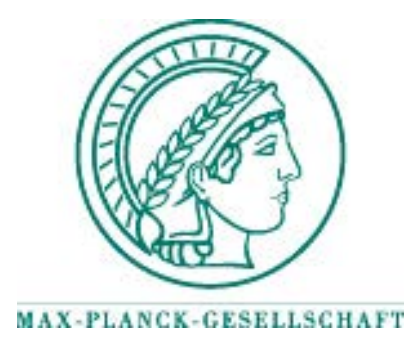

Max Planck Institute for

Tax Law and Public Finance

Department of Business and Tax Law

Department of Public Economics

http:/ / www.tax.mpg.de 
Working papers of the Max Planck Institute for Tax Law and Public Finance Research Paper Series serve to disseminate the research results of work in progress prior to publication to encourage the exchange of ideas and academic debate. Inclusion of a paper in the Research Paper Series does not constitute publication and should not limit publication in any other venue. The preprints published by the Max Planck Institute for Tax Law and Public Finance represent the views of the respective author(s) and not of the Institute as a whole. Copyright remains with the author(s).

Max Planck Institute for Tax Law and Public Finance

Marstallplatz 1

D-80539 Munich

Tel: $\quad+498924246-0$

Fax: $\quad+498924246-501$

E-mail: ssrn@tax.mpg.de

http://www.tax.mpg.de 


\title{
Public-Private Wage Differentials and the Quality of Government Workers in the Philippines
}

\author{
Rhea Molato*
}

May 7, 2015

\begin{abstract}
This paper estimates the wage differential between public sector employees and their private sector counterparts in a developing country, the Philippines. It finds that public sector workers in this country are receiving an hourly wage premium over private sector employees of similar background. This wage premium is associated with a higher degree of pro-social behaviour among government workers relative to private sector workers. However, government employees are found to be working fewer hours than their counterparts in the private sector. College graduates are more likely to work in the government than non-college graduates but among college graduates, those with more specialized skills tend to be employed in the private sector rather than the public sector.
\end{abstract}

* Max Planck Institute for Tax Law and Public Finance. Marstallplatz 1, Munich, Germany 80539. Correspondence: rhea.molato@gmail.com. I thank Davide Cantoni, Erik Hornung, Nadja Dwenger, Aart Gerritsen, Justin Valasek and Kai A. Konrad for helpful comments and suggestions. For granting access to the official data set, I thank the University of the Philippines School of Economics through Stella Quimbo and Joseph Capuno. Finally, I thank Katrina Dinglasan, Loresel Abainza and Raymundo Talento for facilitating access to data I used in this study. 


\section{Introduction}

Wage-setting in the public sector differs from that in the private sector. Basic theory suggests that the market wage rate must be set equal to a worker's marginal output. In the public sector, output takes some non-material form which is not fully observable nor perfectly measurable. By its nature, an employee's output in the public sector does not render itself nearly as measurable as a private sector worker's productivity. As such, his wage rate cannot be simply tied up with his own marginal output that is partly unobservable. This is how determination of wages in the public sector begins to depart from the market standard of setting wage rates. However, competitiveness in the labor market points to the private sector as a reference point when the government as an employer considers sorting among workers. To get an idea of the type of workers who enter the public workforce relative to the kind of workers in the private sector, the relative wage rates between the public and private sectors can give an indication.

This paper measures the difference in hourly wages between public and private sector employees in the Philippines. Upon observing this differential, I proceed with examining the characteristics of public sector workers relative to their private sector counterparts.

Public-private wage differentials are of interest for both developed and developing countries where micro data on individuals and households are used to estimate the wage differentials. Controlling for factors that affect earnings and sector selection, studies find a general pattern where most developed countries pay a wage premium on public sector workers (Krueger 1988 and Poterba and Reuben 1994 for the United States; Disney and Gosling 1998 for the United Kingdom; Mueller 1998 and Mueller 2000 for Canada; Depalo et al. 2011 and de Castro et al. 2013 for a selection of European countries) ${ }^{1}$ while developing countries and transition economies pay lower wages on public sector employees

\footnotetext{
${ }^{1} \mathrm{~A}$ review of existing literature on developed countries can be found in Gregory and Borland 1999.
} 
than on private sector workers (Adamchik and Bedi 2000 for Poland; Panizza et al. 2001 for the Dominican Republic, Nicaragua, Panama and Uruguay; Gorodnichenko and Sabirianova 2007 for Ukraine).

The literature on public service characterizes public sector workers as having higher pro-social motivation than private sector employees (Francois 2000; Francois and Vlassopoulos 2008; Gregg et al. 2011). This pro-social motivation takes various forms, most common among which is altruism. Buurman et al. (2012) and Buurman and Dur (2012) confirm that public sector workers tend to be more altruistic than private sector employees. Apart from being altruistic, government employees are also found to be relatively lazy and risk averse (Bellante and Link 1981; Buurman et al. 2012; Dur and Zoutenbier 2013).

This paper finds that public sector workers in the Philippines are receiving higher hourly wages than private sector workers. It also finds that the Philippine public sector is composed of employees who are more pro-social, who work fewer hours and who are less specialized in skills compared with their private sector counterparts.

The higher wage rates in the public sector indicate that the Philippine government consists of workers who will have received lower wages if they had been employed in the private sector. The market wage rates applicable to these workers are lower than what they are receiving as employees in the government. This finding may serve as a signal on the quality of workers who are presently employed in the Philippine public sector. If the existing pool of government employees have counterparts in the private sector who are subject to lower wage rates, then the quality of these employees corresponds to the quality of their counterparts who are valued by the market at a lower rate.

The rest of the paper is organized as follows. Section 2 describes the micro data set I used and the estimation approach I applied in measuring the publicprivate wage differentials. Section 3 presents the estimated wage differentials in every occupation group. Section 4 proceeds with describing the quality of workers who are presently employed in the Philippine government and which worker qualities are associated with the public wage premium. Section 5 discusses al- 
ternative empirical strategies in measuring the public-private wage differentials and compares them with the main estimation approach used in this paper. Section 6 gives a summary and conclusion. The Appendix contains tables and figures presenting the estimation results.

\section{Data and empirical strategy}

I estimate the public-private wage differentials using data from the merged Labor Force Survey (LFS) and Family Income and Expenditure Survey (FIES), conducted by the National Statistics Office of the Philippines. The LFS contains information on individual-level employment, wages, hours worked and demographics. The FIES includes information on household-level earnings and expenditures. The LFS and FIES are based on cross sectional observations of households drawn from a nationally-representative sample. I incorporate survey weights in all my estimations to account for the complex sampling design. As the set of LFS respondents comprises an overlap with the set of FIES respondents, these two data sets can be merged by the National Statistics Office. I use the latest wave of the merged dataset which is available for the year 2009. This wave covers approximately 38,400 households and 186,800 individuals. ${ }^{2}$

I restrict my sample to employees whose primary occupations belong in private establishments, government, or government corporations. I exclude from the sample all self-employed individuals, employers, family workers, and workers in private households. I also exclude army personnel and government officials (they are not reasonably comparable with any private sector job). This leads to an estimation of 33,998 employees, of whom 6,211 (18\%) belong to the public sector and 27,787 ( $82 \%)$ belong to the private sector.

I use a linear regression model to estimate the wage differentials between public and private sector workers within the same occupation group. ${ }^{3}$ I control

\footnotetext{
${ }^{2}$ More information on the LFS and FIES can be found on the official website of the National Statistics Office of the Philippines: www.census.gov.ph (in English).

${ }^{3}$ Each employee is classified into one of the major occupation groups based on the Philippine
} 
for demographic factors such as gender, age, marital status and family size. In addition, I include control variables for educational attainment and type of educational qualification, variables which can also proxy for unobservable factors affecting an individual's decision to select in either the private or the public sector. Sectoral preferences, for instance, may be reflected in the type of educational background and the level of schooling. I also include region fixed effects to account for variations in standards and costs of living by region of residence.

The regression equation takes a Mincerian form, specified as:

$$
\begin{array}{r}
\ln \left(\text { hwage }_{i}\right)=c+\alpha_{j} \cdot \mathbf{o c c}_{j}+\beta_{j} \cdot\left(\text { pub }_{i} \times \mathbf{o c c}_{j}\right)+\delta \cdot \mathbf{d e m}_{i}+\gamma \cdot \text { slevel }_{i} \\
+\theta \cdot \text { stype }_{i}+\sigma_{r} \cdot \boldsymbol{\mu}_{r}+\varepsilon,
\end{array}
$$

where $h$ wage $_{i}$ is employee $i$ 's hourly wage rate calculated as basic pay per day (in cash) from his primary occupation divided by his normal working hours per day, $\mathbf{o c c}_{j}$ represents a vector of occupation categories, $p u b_{i}$ is an indicator which takes the value 1 if an employee belongs to the public sector and 0 if private sector, $p u b_{i} \times \mathbf{o c c}_{j}$ is an interaction term for public sector workers in every occupation category, $\mathbf{d e m}_{i}$ is a vector of employee $i$ 's demographic characteristics that include age, gender, marital status and family size, slevel $_{i}$ is an indicator for skill level which takes the value 1 if employee $i$ is a college graduate and 0 if non-college graduate, $\mathbf{s t y p e}_{i}$ is a vector of college degree types ${ }^{4}$ representing

Standard Occupation Classification (PSOC). These occupation groups include leaders (executives, managers and supervisors), professionals (teaching professionals, science professionals, health professionals, business professionals and legal professionals), associates (associate teaching professionals, associate science professionals, associate health professionals, associate business professionals and associate legal professionals), clerks, service workers (salespersons and personal service workers), agriculture workers (farmers, forestry workers, fishermen), craft workers (construction workers, metal workers, handicraft workers, food and craft workers), operators (plant operators, machine operators, drivers), unskilled workers (janitors, messengers, market vendors, among others) and a residual group of workers unclassified in the survey. The occupation group of operators is chosen as the reference category.

${ }^{4}$ The types of college degree include arts, social sciences, physical sciences, engineering, health sciences, agriculture, education, services and general programs. General college degree 
employee $i$ 's specialization in skills, $\boldsymbol{\mu}_{r}$ controls for region fixed effects, ${ }^{5}$ and $\varepsilon$ is an error term which is assumed to be uncorrelated with the covariates. Age and its squared form, $a g e^{2}$, are used as proxy for experience because age is proportional with experience and the survey does not contain a direct question on employees' work experience.

The variable of interest is the vector $\beta_{j}$ which represents the wage differential between public sector and private sector employees within each occupation group $j$. Positive values of $\beta_{j}$ indicate that public sector workers are receiving a wage premium over their private sector counterparts while negative values of $\beta_{j}$ indicate a wage penalty on public sector workers relative to their equivalents in the private sector. I estimate the value of $\beta_{j}$ through survey-weighted Ordinary Least Squares (OLS).

Table 1 (in the Appendix) summarizes the average hourly wage rates among all workers and within each occupation group. Public sector workers in general earn higher average wages than private sector workers. The difference in average wages is more pronounced among associates, service workers, craft workers and unskilled workers. Among professionals and operators, the average wage of public sector workers are almost as much as the average wage of private sector employees.

While the averages in Table 1 are indicative of an overall positive wage gap between public and private sector workers, a proper comparison within each occupation group requires controlling for observable factors that may explain individual earnings. Table 2 shows that public and private sector employees differ in observable characteristics. On average, government employees are older than private sector employees, are composed of more female workers and more married persons, belong to households of smaller family size, and are composed is the reference category.

${ }^{5}$ The regions represented in the sample are Ilocos, Cagayan, Central Luzon, Bicol, Western Visayas, Central Visayas, Eastern Visayas, Zamboanga, Northern Mindanao, SOCCSKSARGEN, Davao, National Capital Region, Cordillera Administrative Region, Autonomous Region in Muslim Mindanao, CARAGA, CALABARZON and MIMAROPA. Ilocos Region is used as the reference category. 
of more college graduates relative to private sector workers. These factors are correlated with higher wages ${ }^{6}$ (see Table 3 ). To properly estimate the wage differential between public sector employees and their private sector counterparts, it is important to control for these observable factors so that only the wages of workers with similar background can be compared. The results of this estimation are presented in the next section.

\section{Public-private wage differential}

Table 4 presents the wage gap by occupation group estimated through OLS using the linear regression model in eq. (1). Because I take the natural logarithmic values of hourly wage as dependent variable, the coefficient estimates of $\beta_{j}$ represent the estimated difference in hourly wages as a percentage of private sector workers' hourly wage.

\subsection{Without region fixed effects}

Column (1) shows the estimated wage gap controlling for demographic factors, skill level, skill types and occupation fixed effects, without including region fixed effects. This estimation procedure compares employees residing across the whole country. The estimation results show significant differences in wage rates between the public and the private sectors. Public sector workers taking on leadership positions (executives, managers and supervisors) receive hourly wages that are 20.9 percent more than the hourly wages of their counterparts in the private sector (p-value: 0 ). Likewise, professionals in the public sector receive a wage premium of $14.8 \%$ ( $\mathrm{p}$-value: 0 ).

Service workers are found to receive the highest wage premium in the public sector, equivalent to $22.4 \%$ of private service workers' hourly wage. This esti-

\footnotetext{
${ }^{6}$ In contrast to many other countries, women in the Philippines earn higher wages than men on average. This is supported by empirical studies (for example, Sakellariou 2004) which elaborate that women's higher average wages can be explained by higher levels of human capital investment among women.
} 
mate is statistically significant up to the $1 \%$ level (p-value: 0 ). Service workers refer to those who provide personal and protective services (according to the Philippine Standard Occupation Classification). Their jobs include child care, preparation and serving of food and beverages, fire-fighting, police work and sales. The large premium in the public sector for service workers may be due to strong competition within the private sector. The service industry comprises $47.5 \%$ of the Philippine economy ${ }^{7}$ and thus a major fraction of the labor force. Strong competition in the private labor market may be driving down the private sector wage rate which translates into a higher premium in the public sector where wages are standardized by law.

Unskilled public sector employees, whose jobs include office helpers and cleaners, messengers, doorkeepers and garbage collectors, receive $15.9 \%$ more than their counterparts in the private sector (p-value: 0). Agriculture workers in the public sector are also found to receive a wage premium over private agriculture workers (approximately 18.2\%) even though the wage premium is less precisely estimated for this group (p-value: 0.121). The wage gaps estimated for associates, craft workers and unclassified workers (which are all negative) are economically and statistically insignificant.

Finally, estimates that do not control for region fixed effects show that clerks in government offices are receiving lower wages than private sector clerks residing across the whole country. This wage penalty of $14.3 \%$ is both economically significant and statistically significant at the $1 \%$ level (p-value: 0$)$. This can be interpreted to mean that a government clerk in one region is earning less than a private clerk who could be living in another region. We need to verify whether this wage differential is due to geographical location or not. In other words, we need to see whether the wage penalty remains if we compare public and private sector clerks residing in the same region. If it disappears, then this wage gap can be attributed merely to regional variations in living standards and not on the sector of employment.

\footnotetext{
${ }^{7}$ Source: National Statistical Coordination Board
} 


\subsection{With region fixed effects}

In column (2), I control for region fixed effects in order to compare employees within the same region. Controlling for region fixed effects filters away institutional factors that may vary across regions. Such regional variation is supported by statistical accounts in Table 5 which shows how per capita levels of consumption vary by region. For instance, consumption in the National Capital Region is equivalent to $186 \%$ of the national average while in a region like Northern Mindanao, consumption is as low as $75 \%$ and in the poorest region (ARMM), consumption is only $46 \%$ of the national average.

Estimates in column (2) of Table 4 indicate that the public-private wage differentials are positive, if not statistically different from zero, across all occupation groups. It signifies that public sector employees compared to their private sector counterparts within the same region are actually receiving a higher wage rate. The public wage premium is highest among leaders, $33.6 \%$ (p-value: 0 ). This is followed by the wage premium among public professionals, $27.5 \%$ (p-value: 0), and public sector service workers, $25.4 \%$ (p-value: 0$)$. Even after controlling for region fixed effects, the public wage premium for unskilled workers remain positive at $11.3 \%$ (p-value: 0 ).

Contrary to the estimate in column (1), public sector associates are found to receive higher wage rates (5.8\%; p-value: 0.113$)$ compared to private sector associates in the same region. The reversal of direction in column (2) indicates that the (insignificant) wage penalty earlier estimated for public sector associates may be due to regional heterogeneity. Indeed, an inspection of geographic distribution in Table 6 reveals that private sector associates are more concentrated in regions characterized with higher standards of living (National Capital Region and CALABARZON, where consumption per capita are above the national average), while public sector associates are evenly dispersed across all regions. This explains the private wage advantage displayed in column (1) that was overturned after controlling for region fixed effects in column (2).

The private sector wage advantage for clerks and craft workers disappear 
once region fixed effects are controlled for. This indicates that public and private sector clerks (craft workers) residing in the same region are receiving basically equivalent hourly wage rates. This finding reflects a similar situation as associates in terms of geographic distribution. Table 6 reveals that a majority of private sector clerks and craft workers are located in regions where per capita consumption levels are above the national average. Thus, the private sector wage advantage estimated for these occupation groups in column (1) appears as a consequence of comparing public sector workers with private sector employees who are mostly concentrated in regions with higher standards of living. When comparing employees located in the same region, it occurs that clerks and craft workers in the public and private sectors are not subject to a significant wage differential.

The wage premium for public agriculture workers remain positive but statistically insignificant. It cannot be said that farmers, fishermen and forestry workers employed by the government are earning more than the private agriculture workers in the same region.

\subsection{Richer regions vs. poorer regions}

In Table 7, I present wage differentials within each of two subsets of regions classified according to economic activity. Richer regions refer to those with consumption per capita on or above the median while poorer regions pertain to those below the median consumption level. It shows that in most cases, the public wage premium is higher within the subset of poorer regions. For instance, public sector professionals are receiving a wage premium of $44.4 \%$ in poorer regions (p-value: 0 ) and only $9.1 \%$ in richer regions (p-value: 0$)$. Service workers receive a public wage premium of $53.0 \%$ in poorer regions (p-value: 0 ) compared to $14.9 \%$ in richer regions (p-value: 0$)$. These large premia may be explained by weaker competition between the public and private sectors in poorer regions where the economy is less vibrant and thus private sector wages are lower than in richer regions. Richer regions, on the other hand, have a 
competitive private sector where market wage rates can catch up with public sector wage rates.

\subsection{By age bracket}

In this sub-section, I show how the public-private wage differentials vary with years of experience. Public sector workers may have longer years of work experience relative to private sector workers, which make them more eligible for higher pay. Indeed, Table 2 supports that on average, government workers are older than private sector employees. Since experience is directly proportional with age, government employees can be said to have more years of work experience than private sector employees on average. The OLS estimates presented in Tables 4 and 7 account for this potential endogeneity by including age and age ${ }^{2}$ as proxy for experience among the demographic variables. These explanatory variables turn up with the expected coefficients: positive for age, $2.3 \%$, and negative for $a g e^{2},-0.023 \%$, both statistically significant at the $1 \%$ level. These estimates confirm the standard inverted U-shaped relationship between age and wages - increasing during early years and decreasing later on.

In order to observe the pattern between experience and the public wage premium, I estimate the public-private wage gap at different age brackets. I sub-divide the sample into 5-year age groups and apply OLS on eq. (1) for eage age bracket. The idea is to group together employees who have more or less similar years of work experience and to find the pattern in observed wage differentials between less experienced workers and more experienced workers. These OLS estimates used the full set of demographic variables except age and $a g e^{2}$.

Figure 1 (in the Appendix) illustrates the pattern between experience and the public wage premium on four occupation groups where the estimated differentials are statistically significant: leaders, professionals, service workers and unskilled workers. It depicts an inverted U-shaped pattern similar to the relationship earlier found between age and hourly wage rates. It shows that the 
public wage premium varies with age, and thus experience, and remains positive throughout most of an employee's career. Among employees of similar experience levels, the public sector employees appear to be receiving a premium over their private sector cohorts.

\subsection{By gender}

On average, the proportion of females to males in the public sector is higher than the proportion in the private sector (Table 2). I proceed with examining whether women are receiving a higher or lower public wage premium compared to men. I sub-divide the sample into two groups, male and female, and apply OLS to estimate eq. (1) in each group. This allows me to estimate the public wage premium within the sub-sample of women and compare it with the public wage premium within the sub-sample of men. These regressions used the full set of demographic variables except gender.

Table 8 shows that the difference in the levels of public wage premia between men and women vary depending on the occupation group. Among leaders and among professionals, women are receiving a higher public wage premium than the public wage premium received by men. Female leaders in the public sector are receiving $46.1 \%$ more (p-value: 0 ) than female leaders in the private sector. Male leaders, on the other hand, are receiving a public wage premium of $20.6 \%$ (p-value: 0.001) over their counterparts in the private sector. Female professionals employed in the government earn $34.6 \%$ more (p-value: 0 ) than their counterpart female professionals in private establishments. On the other hand, male professionals in the government receive a wage premium of $13.2 \%$ (p-value: 0.001) over male professionals employed in the private sector.

For service workers, the story is different. Female service workers are receiving a lower public wage premium (15.7\%; p-value: 0.033$)$ than male service workers (25.4\%; p-value: 0). Among unskilled workers, the public wage premium among men remains positive and significant (13.4\%; p-value: 0$)$ while the public wage premium among women disappears. 


\section{The quality of government workers}

In this section, I describe the type of workers in the public sector relative to their counterparts in the private sector. Then I examine the qualities of government employees associated with the public wage premium measured in the previous section.

\subsection{Skill level and skill types}

One may wonder whether the wage premium observed in the public sector reflects positive skill selection among government workers. In other words, could it be that public sector workers are better-skilled than their private sector counterparts? It can be seen in Table 2 that a higher percentage of government employees are college graduates (55\%) compared to only $15 \%$ among private sector employees. I proceed with testing whether public sector workers are equipped with superior skill levels and skill types within each occupation group, controlling for observable factors such as gender, age, civil status, family size and region fixed effects.

For every occupation group $j$, I estimate the following probit model on employee $i$ 's probability of being in the public sector:

$$
\operatorname{Pr}\left(p u b_{i \in j}\right)=c+\delta_{j} \cdot \mathbf{d e m}_{i \in j}+\gamma_{j} \cdot \text { slevel }_{i \in j}+\theta_{j} \cdot \text { stype }_{i \in j}+\sigma_{j} \cdot \boldsymbol{\mu}_{r}+\varepsilon_{j}
$$

where $p u b_{i \in j}$ is an indicator which takes the value 1 if employee $i$ in occupation group $j$ belongs to the public sector and 0 if private sector, $\mathbf{d e m}_{i \in j}$ represents the demographic characteristics of employee $i$ in occupation group $j$, slevel $l_{i \in j}$ refers to the skill level attained by employee $i$ in occupation group $j$, stype $_{i \in j}$ pertains to the skill type acquired by employee $i$ in occupation group $j, \boldsymbol{\mu}_{r}$ stands for region fixed effects and $\varepsilon_{j}$ is the error term. Skill level is measured by a dichotomy between college graduates and non-college graduates (non-college degree holders are taken as reference group in skill level). Skill types are distinguished according to the category of college degrees (among college graduates), with general college degree as reference category. General college degrees com- 
prise Bachelor of Arts and Bachelor of Science programs with no field of specialization (based on the Philippine Standard Classification of Education). The specialized skill types belong to one of the following college degrees: education, arts, social sciences, physical sciences, engineering, agriculture, health sciences and services. The probit estimates on each of these college degrees, represented by $\widehat{\theta}_{j}$, represent the relative probability of working in the public sector for college graduates with a specialized degree compared to college graduates with a non-specialized degree.

Table 9 presents the marginal effects resulting from this probit estimation. It shows that among employees in the leaders' occupation group, college graduates are more likely to be in the public sector. Service workers who have obtained a college degree are also significantly more likely than non-college graduates to be employed in the government. Thus, the public wage premia among leaders (33.6\% based on Table 4) and service workers (25.4\%) can be explained in part by their higher skill levels in terms of college educational attainment.

On the other hand, college graduates who are working as professionals are not significantly more likely to choose employment in the public sector. The wage premium that public sector professionals are receiving $(27.5 \%)$ cannot be associated with higher skill levels among government employees in this occupation category.

Among employees classified as unskilled workers (helpers, cleaners, messengers, and others) the public wage premium (11.3\%) is associated with higher skill level among government-employed workers. College graduates in this occupation category are significantly more likely to be in the public sector compared with non-college graduates. Public sector employees in this occupation category comprise $5 \%$ of all workers who report unskilled jobs as their primary occupation. Among public sector workers in this group, $7 \%$ are college graduates compared to $1 \%$ among the private sector workers. Unskilled workers in the public sector usually take on jobs as helpers and cleaners in offices, sweepers, construction and maintenance laborers, messengers, package and luggage porters while those in the private sector include farmhands and other manual 
farm laborers, hand packers and other manufacturing manual laborers, construction and maintenance laborers, helpers and cleaners in offices and hotels, messengers, package and luggage porters.

Analysis can also be made on whether the public wage premium reflects specialization in the type of skills that public sector workers possess. Table 9 shows that employees with more specialized college degrees are in many cases less likely to be working in the public sector. Among leaders, those with a college degree in education, social science, physical science, engineering, agriculture and services are significantly less likely to be in the public sector compared to those with non-specialized college degrees (Bachelor of Arts and Bachelor of Science in general programs).

Only among professionals is one specialized degree more inclined to be in the public sector. Professionals holding a college degree in education are signficantly more likely to be government employees. This observation is in line with the fact that this occupation group consists of teaching professionals $(60.47 \%$ in the sample) and public sector professionals in general receive a significantly positive wage premium over private sector professionals (27.5\%).

The rest of the occupation groups exhibit either a negative probability or a non-significant difference in probability of public sector employment among workers holding a specialized college degree. While this paper does not seek to explain the reasons behind these differences in probability, it shows that the differential probabilities (when they are significant) are not associated with the public wage premium except for teaching professionals. Specifically, the public wage premium among leaders, service workers and unskilled workers do not reflect more specialization in skill types in the public sector.

\subsection{Effort level}

Among the ranks of objective factors associated with the public-private wage differential, another candidate points to the level of effort that public sector employees exert on the same type of job. I estimate the public-private differential 
in effort levels measured by the employees' response to a survey question on total number of hours worked during the past week. ${ }^{8}$ Total number of hours worked is an observable measure of effort that is also used in standard empirical studies. Although it does not perfectly capture effort in a strict sense, other dimensions of effort are not as directly measurable as hours worked. Thus, I take this variable as proxy for effort level, which is reported in the survey data.

To estimate the public-private differential in hours worked, I use the following regression equation:

$$
\begin{aligned}
\text { hours }_{i}=c+\phi_{j} \cdot \mathbf{o c c}_{j}+\lambda_{j} \cdot\left(\text { pub }_{i} \times \mathbf{o c c}_{j}\right)+ & \delta \cdot \mathbf{d e m}_{i}+\gamma \cdot \text { slevel }_{i} \\
& +\theta \cdot \mathbf{s t y p e}_{i}+\sigma_{r} \cdot \boldsymbol{\mu}_{r}+\varepsilon,
\end{aligned}
$$

where hour $s_{i}$ refer to employee $i$ 's total number of hours worked in one week, and the covariates $\mathbf{o c c}_{j}$, pub $_{i}, \mathbf{d e m}_{i}$, slevel $_{i}, \mathbf{s t y p e}_{i}$ and $\boldsymbol{\mu}_{r}$ are as defined in Section 2 for eq. (1). Controlling for occupation fixed effects through the vector $\mathbf{o c c}_{j}$ effectively accounts for occupation-specific demands on effort level. The variable of interest, $\lambda_{j}$, captures the differential in total hours worked between public and private sector workers within the same occupation group.

Table 10 reports the hours differential estimated through OLS. In contrast to the positive wage premium observed for public sector workers, it shows that government employees report less hours of work than their counterparts in the private sector. Public sector executives, managers and supervisors work 2.34 hours less in a week compared with executives, managers and supervisors in the private sector (p-value: 0.001). Significant differences are also observed among public sector associates, who work 4.65 hours less than their private sector counterparts (p-value: 0), public sector clerks (4.53 hours less; p-value: 0 ), public sector service workers (10.46 hours less; p-value: 0$)$ and public sector craft workers (1.90 hours less; p-value: 0.014). Professionals in the civil service also tend to report fewer hours of work than counterpart professionals in the private sector (0.70 hours; p-value: 0.072$)$ although this difference is smaller

\footnotetext{
${ }^{8}$ This is not the same variable I used in calculating the hourly wage rate. For the hourly wage rate, I used as denominator the number of normal working hours per day.
} 
than the hours differential in other occupation groups.

Public sector workers are generally found to work fewer hours than their counterparts in the private sector, and thus exert less effort, while they receive higher wage rates. Figure 2 illustrates the discrepancy in wages and effort levels between public and private sector employees in each occupation category. It depicts the irony that government employees are earning higher wages than their equivalents in the private sector yet they are exerting less effort. This is consistent with other studies, both theoretical and empirical, which find that in general government employees exert less effort than private sector workers (for example, Buurman et al. 2012 and Dur and Zoutenbier 2013).

\subsection{Pro-social motivation}

The analysis so far cannot in large part associate the observed public wage premium with public employees' effort levels nor specialization in skills. Examining the wage premium then leads one to check out other dimensions that distinguish public sector workers from private sector employees.

There is a growing consensus in the literature that individuals with more prosocial orientation tend to select into the public sector (Francois 2000; Francois and Vlassopoulos 2008; Gregg et al. 2011; Buurman et al. 2012; Buurman and Dur 2012). In this sub-section, I show that public sector employees in the Philippines exhibit higher levels of pro-social behaviour relative to their private sector counterparts. Moreover, this pro-social premium corresponds with the public wage premium described in the previous section. I measure prosocial behaviour as a household's total gifts and contributions to others, a value reported in the survey data as the sum of gifts and contributions outside the family, contributions to church, contributions to other institutions, and other gifts and contributions. Giving behaviour represents pro-social motivation in the sense that it consists of transfers for the benefit of its recipients while involving tangible costs to the benefactor. While there are arguably many forms of prosocial action and pro-social motivation itself, in its pure form, is not perfectly 
measurable, giving behaviour is both directly observable and directly correlated with pro-social motivation. For this reason, I use the value of total gifts and contributions as a proxy measure of pro-social motivation.

I estimate the public-private differentials in giving behaviour through the following linear regression:

$$
\begin{aligned}
& \ln \left(\text { gifts }_{m}\right)=c+\phi_{j} \cdot \mathbf{o c c}_{j}+\tau_{j} \cdot\left(\text { pub }_{i} \times \mathbf{o c c}_{j}\right)+\delta \cdot \mathbf{d e m}_{i}+\gamma \cdot \text { slevel }_{i} \\
&+\theta \cdot \text { stype }_{i}+\sigma_{r} \cdot \boldsymbol{\mu}_{r}+\varphi \cdot \text { hwage }_{i}+\varepsilon
\end{aligned}
$$

where gifts $_{m}$ refer to the total value of gifts given by household $m$ where employee $i$ belongs, hwage $i$ is the hourly wage rate received by employee $i$, and the rest of the covariates are as defined in Section 2 for eq. (1). Controlling for hourly wage rates allows for comparison of giving behaviour among employees of the same income levels and eliminates the pure income effect on giving.

The variable of interest is $\tau_{j}$ which stands for the difference in the value of gifts given by households where public sector employees belong and the value of gifts given by households where private sector employees belong. Table 11 presents the results of this estimation procedure. It shows that public sector employees belong to households who give substantially more than the households where private sector employees belong, holding all other observable factors constant. In every occupation group (except agriculture workers, where the public sector consists only 1\%), the public sector premium in gift-giving is economically and statistically significant. For instance, the public-private differential in gift-giving among professionals is equivalent to $25.6 \%$ of total gifts given by households where private sector professionals belong (p-value: 0). Likewise, service workers in the public sector are giving more with the difference equivalent to $25 \%$ of the total gifts given by their counterparts in the private sector (p-value: 0.001).

Figure 3 illustrates the association between the public wage premium and the public premium in pro-social behaviour. In occupation groups with significant levels of public wage premium (leaders, professionals, service workers and unskilled workers), the corresponding premium in pro-social behaviour is 
also substantial. For each of these occupation groups, the pro-social premium among government employees is of almost equal size as, if not bigger than, its respective public wage premium.

The wage advantage that public sector workers receive in comparison to their private sector colleagues are found to reflect the higher level of pro-social behaviour that government workers exhibit relative to private sector employees. Among the factors examined in this paper, pro-social behaviour is by far the one most consistently associated with the public wage premium. It is worth examining whether this differential in giving behaviour may be motivated by less altruistic reasons like reciprocity. It can be checked whether public sector employees are giving more in expectation of receving more in return. This can be analyzed from column (2) in Table 11. It shows the public-private differential in gifts received by household $m$ where employee $i$ belongs, estimated using the same set of regressors in eq. (4). I use $\ln$ (gifts received) as outcome variable so the estimates of $\tau_{j}$ in this case express the public-private differential as a proportion of gifts received by households where private sector employees belong.

Column (2) shows that in most occupation groups, the value of gifts received by households where public sector employees belong is not significantly different from the value of gifts received by households where their private sector counterparts belong. Thus, it does not give evidence that the public premium in gift giving is met with a corresponding premium on gifts received by public sector workers. In cases where the difference is weakly significant (at the $10 \%$ level), public sector employees appear to be receiving less gifts. Only the group of unskilled workers stand out. Unskilled workers in the public sector are found to be receiving more gifts than their counterparts in the private sector (13.7\%; p-value: 0.044) and this difference is statistically significant. These public sector unskilled workers are also giving more than those in the private sector (40.6\%; p-value: 0) as column (1) indicates. For this group, the publicprivate differential in net gifts given may be more salient. Net gifts given by household $m$ where employee $i$ belongs is measured as the difference between total gifts and contributions to others and the value of gifts it received. Column 
(3) shows that the net gifts given by households where public sector unskilled workers belong is higher than the net gifts given by the households of their private sector counterparts. The difference is estimated as $21.8 \%$ of the net gifts given by households of private sector unskilled workers (p-value: 0.085). This public-private differential is closer to the size of the public wage premium (11.3\%; p-value: 0) earlier found for unskilled workers than is the differential in total gifts given (40.6\%; p-value:0). Thus, the public-private differential in net gifts given by unskilled workers is a better reflection of the public wage premium in this occupation group. Nevertheless, the positive association between pro-social behaviour and public wage premium remains across all occupation groups where the public-private wage differentials are significant.

\subsection{Risk aversion}

Since the government offers more job security and predictability than private sector employers, it may be inclined to attract workers who are more risk averse than private sector workers. Existing studies in other countries confirm this hypothesis (Bellante and Link 1981; Buurman et al. 2012; Dur and Zoutenbier 2014). In this sub-section I test whether public and private sector workers in the Philippines exhibit different levels of risk aversion and if so, whether this difference corresponds to their wage differentials.

I compare risk aversion levels between public and private employees using proxy indicators of risk aversion available in the data set. The only proxy variables contained in the survey which can capture some aspects of risk aversion are tobacco consumption and spending on alcoholic beverages, both at the household level. Because these two commodities pose health risks, lower consumption levels may indicate higher degrees of risk aversion. I estimate differential rates of risk aversion between public and private sector workers based on consumption 
of commodity $k \in\{$ tobacco, alcohol $\}$ with the following regression equation:

$$
\begin{array}{r}
\ln \left(\operatorname{con}_{m}^{k}\right)=c^{k}+\phi_{j}^{k} \cdot \mathbf{o c c}_{j}+\rho_{j}^{k} \cdot\left(\text { pub }_{i} \times \mathbf{o c c}_{j}\right)+\delta^{k} \cdot \mathbf{d e m}_{i}+\gamma^{k} \cdot \text { slevel }_{i} \\
+\theta^{k} \cdot \text { stype }_{i}+\sigma_{r}^{k} \cdot \boldsymbol{\mu}_{r}+\varphi^{k} \cdot \text { hwage }_{i}+\varepsilon,
\end{array}
$$

where $\operatorname{con}_{m}^{k}$ is total expenditure on risk commodity $k$ in household $m$ where employee $i$ belongs, hwage ${ }_{i}$ is the hourly wage rate that employee $i$ earns, and the rest of the covariates are as described before. By including the hourly wage rate, this equation controls for income effects on consumption and effectively compares public and private sector employees at similar income levels.

The variable of interest is $\rho_{j}^{k}$ which represents the difference in risk-taking behaviour between public and private sector employees in occupation group $j$. Table 12 presents the public-private differentials in risk-taking in terms of tobacco consumption (column 1) and alcoholic beverage consumption (column 2). It shows that there is no statistically significant difference in tobacco consumption between public and private workers across all occupation groups. If risk aversion is measured in terms of consumption of a health-risk commodity such as tobacco, then there is no observed difference in risk aversion levels between the two sectors. On the other hand, if risk aversion is measured in terms of spending on alcoholic beverages, then some differentials turn up in some occupation groups. These are the same occupation groups for which the highest levels of public-private wage gaps were observed. Leaders and professionals employed in the government report lower consumption levels of alcoholic beverages compared with their private sector counterparts who earn the same wage rates. This can indicate that government executives, managers, supervisors and professionals may be more risk averse than their equivalents in the private sector. In a way, part of the public wage premium these employees are receiving may be interpreted as compensation for their risk aversion.

On the contrary, government workers in the services sector as well as publiclyemployed unskilled workers, who likewise enjoy substantial wage premia, tend to consume more alcoholic beverages than their private sector counterparts. Public sector employees in these occupation categories may be construed as being less 
risk averse. Thus, the wage premium they are receiving cannot be expressed as compensation for risk aversion.

Figure 4 summarizes the comparison of public-private wage gaps and risk aversion differentials in these four occupation groups. The public wage premium for leaders and professionals corresponds with higher degrees of risk aversion. For service workers and unskilled workers, the public wage premium corresponds with lower levels of risk aversion relative to their counterparts in the private sector.

\section{$5 \quad$ Alternative estimation strategies}

In this section, I describe alternative approaches in estimating the public-private wage differentials and show that the estimates in Section 3 are robust to an alternative matching strategy. These approaches sub-divide the sample into occupation groups and estimate the wage gap within each sub-sample. One strategy is standard in the empirical literature and applies OLS in estimating the public-private wage differentials. Another approach is to match individuals based on propensity scores and measure the wage difference between public employees and their resulting matches in the private sector. These alternative approaches have advantages and disadvantages compared with the main empirical strategy I have employed in this paper. By splitting the sample into occupation groups, each estimation makes use of fewer observations and thus carries lower statistical power. On the other hand, propensity score matching (PSM) has the intuitive appeal of identifying reasonable matches with which to compare public sector employees. In this section, I show that the OLS estimates within sub-samples suffer from poorer fit compared with the full sample estimates as a consequence of the smaller size. As a result, its estimates of the wage differentials are lower in magnitude although they display the same direction and levels of significance. On the other hand, estimates based on PSM are close to the full sample estimates described earlier, in terms of magnitude, direction and statistical significance. This matching approach provides further 
support to the estimates of public-private wage differentials measured through this paper's main empirical strategy described in Section 2.

\subsection{OLS within each occupation group}

With this approach, the public-private wage differential in each occupation group $j$ is estimated by OLS from the following equation:

$$
\begin{aligned}
\ln \left(\text { hwage }_{i \in j}\right)=c+\widetilde{\beta_{j}} \cdot p u b_{i \in j}+\widetilde{\delta_{j}} \cdot \mathbf{d e m}_{i \in j} & +\widetilde{\gamma_{j}} \cdot \text { slevel }_{i \in j} \\
& +\widetilde{\theta} \cdot \text { stype }_{i \in j}+\widetilde{\sigma_{r}} \cdot \boldsymbol{\mu}_{r}+\varepsilon
\end{aligned}
$$

where $p u b_{i \in j}$ is an indicator which takes the value 1 if employee $i$ in occupation $j$ belongs to the public sector and 0 if private sector, and the rest of the covariates for each individual $i$ belonging to occupation group $j$ are as explained previously

for eq. (2). The variable of interest is $\widetilde{\beta_{j}}$ which measures the difference in wages between public and private sector employees in the sub-sample of each occupation group. Table 13 presents the results of this estimation approach vis-a-vis the full sample estimates described earlier (from Table 4 column 2). It shows positive and significant public wage premia in the same occupation groups where the full sample regressions revealed significant wage differentials. However, the sizes of these differentials are mostly smaller in the sub-sample regressions. For leaders, the public wage premium is estimated at $17.8 \%$ (pvalue: 0.001 ), lower than the $33.6 \%$ public wage premium (p-value: 0 ) estimated in the full sample. For professionals, it is $15.6 \%$ (p-value: 0) compared with the $27.5 \%$ (p-value: 0) in the full sample. For service workers, the public wage gap is estimated at $21.3 \%$ (p-value: 0 ) in the sub-sample regression, lower than the $25.4 \%$ (p-value: 0) found in the full sample. For unskilled workers, the estimated public wage premium within the sub-sample is $14.9 \%$ (p-value: 0 ), slightly higher than the $11.3 \%$ wage premium (p-value: 0 ) estimated from the full sample.

Each sub-sample regression in Table 13 displays lower levels of adjusted Rsquared compared with the full sample regression so it cannot be considered a 
better fit. The resulting estimates of the public-private wage differentials cannot be considered more precise than the full sample estimates described in Section 3. At best, they confirm that public sector employees are receiving a wage premium over their private sector counterparts. For more precise estimates of the size of this wage premium, I turn to another alternative approach that involves matching employees in the public and private sectors within each occupation group.

\subsection{PSM within each occupation group}

With propensity score matching, employees in the public sector are matched with their counterparts in the private sector based on the conditional probability of working in the public sector given a set of observed covariates. This conditional probability is summarized in propensity scores. Private sector employees within the neighborhood of each public sector employee's propensity score are considered good matches with which to compare wages. The wage differential due to sector of employment is measured as the difference in observed wages between public sector employees and their resulting matches from the private sector in the same occupation group.

To generate propensity scores, I use the same set of covariates in eq. (6) :

$$
X \in\left\{\text { dem }_{i \in j}, \text { slevel }_{i \in j}, \text { stype }_{i \in j}, \boldsymbol{\mu}_{r}\right\}
$$

for each employee $i$ in occupation $j$. Based on these propensity scores, public sector employees are matched with their private sector equivalents (I use the matching algorithm which takes the nearest 5 neighbors, with replacement).

Table 14 presents the results of propensity score matching within each occupation group. In occupation groups where matching was properly achieved, the wage differentials, represented by the average treatment effects on the treated (ATT), resemble the OLS estimates of wage differentials from the full sample. (Estimates of ATT represent the difference between public sector employees' actual wage rates and their counterfactual wage rates if they had been employed in the private sector instead). For instance, the public wage premium on 
professionals is estimated as $28.5 \%$ by PSM, statistically significant at the $1 \%$ level, just like the $27.5 \%$ wage premium estimated by OLS from the full sample. For service workers, PSM found a public wage premium of $30.3 \%$ (statistically significant at the $1 \%$ level) compared with $25.4 \%$ premium (also statistically significant at the $1 \%$ level) estimated from the full sample. For unskilled workers the public wage premium is estimated by PSM at $15.4 \%$ whereas it is measured at $11.3 \%$ by OLS from the full sample (in both cases, statistically significant at the $1 \%$ level).

While the concept of propensity score matching identifies an objective procedure in matching public and private sector employees, one drawback in estimating the wage differential by PSM is that proper matching cannot be achieved in some cases. In particular, the group of leaders in the public sector cannot be properly matched with their private sector counterparts based on propensity scores. The standardized bias in covariate matching within this occupation group is $7.44 \%$, higher than the maximum acceptable standardized bias (5\%) in most studies that use PSM (Caliendo and Kopeinig, 2008). In addition, the Pseudo R-squared is not low (0.373) which is a further indication that the match quality is not satisfactory. For this reason, estimates of ATT and thus the wage differential between public and private sector leaders cannot be reported as valid. The same is true for the case of agriculture workers and unclassified workers, for which I do not report estimates of the wage differentials.

Nonetheless, matching by propensity scores validates the estimates of publicprivate wage differentials generated through the main empirical strategy in this paper. It confirms that public sector employees in the Philippines are receiving a wage premium over their counterparts in the private sector. Moreover, the size of this wage premium estimated by OLS from the full sample is virtually precise if we take results from the matching procedure as a point of comparison. 


\section{Summary and conclusion}

This paper finds that public sector workers in the Philippines are receiving higher hourly wage rates compared with their counterparts in the private sector. This situation is different from other developing countries where government employees appear to be receiving lower wage rates than private sector employees.

This study also demonstrates that the public wage premium in the Philippines is being paid on employees whose skills are less specialized, who exert less effort but altogether are more pro-social than their private sector counterparts. While this paper does not attempt to explain the reasons behind these wage differentials nor the process involved in setting wages, it describes the relationship between the public wage premium and the quality of public workforce in the Philippines.

This study finds that employees in occupation groups subject to a higher public wage premium are characterized with more pro-social behaviour. Among the traits examined in this paper, pro-social behaviour is the quality that is most consistent and clearly associated with the public wage premium. This observation establishes that higher wages in the public sector corresponds with more pro-social motivation among government workers.

Differentials in effort level also reveal systematic results. While government employees are found to receive higher wages relative to their private sector counterparts, they are also found to be working fewer hours.

This paper finds that college graduates are more likely to work for the public sector than are non-college graduates. However, among college graduates, those who obtained more specialized degrees tend to be employed in private establishments rather than in government agencies. As a result, government employees are characterized with skills that are less specialized than those of private sector employees. Thus, the public wage premium cannot be interpreted as a premium for skill specialization in the government's workforce.

The findings of this paper signify that the existing set of public sector workers consists of employees who would have been receiving lower wages if they 
had been employed in the private sector. In other words, their private market value is lower than what they are presently earning because their counterparts employed in the private sector are receiving lower wages. If the private sector wage rate reflects the quality of its own employees, then the lower wages that private employers pay the counterparts of existing public sector workers serve as an indication of the actual quality of these government employees. Their counterparts are those who are receiving lower wage rates and are therefore of lower quality by market standards. 


\section{Appendix}

Table 1. Average hourly wages, 2009 (in current Philippine pesos)

\begin{tabular}{|c|c|c|c|}
\hline & $\begin{array}{c}\text { Public } \\
\text { (1) }\end{array}$ & $\begin{array}{c}\text { Private } \\
\text { (2) }\end{array}$ & $\begin{array}{c}\text { Difference } \\
\text { (Public-Private) } \\
(3) \\
\end{array}$ \\
\hline \multirow[t]{2}{*}{ All occupations } & $\begin{array}{c}63.632 \\
(43.564)\end{array}$ & $\begin{array}{c}35.889 \\
(59.305)\end{array}$ & $\begin{array}{l}27.744^{* * *} \\
(0.882)\end{array}$ \\
\hline & 5,034 & 24,099 & \\
\hline \multirow[t]{2}{*}{ Leaders } & $\begin{array}{r}112.553 \\
(60.978)\end{array}$ & $\begin{array}{c}103.546 \\
(187.498)\end{array}$ & $\begin{array}{r}9.007 \\
(13.082)\end{array}$ \\
\hline & 211 & 840 & \\
\hline \multirow[t]{3}{*}{ Professionals } & 81.345 & 80.845 & 0.500 \\
\hline & $(34.753)$ & $(60.077)$ & $(1.761)$ \\
\hline & 1,781 & 1,123 & \\
\hline \multirow[t]{2}{*}{ Associates } & $\begin{array}{c}63.050 \\
(38.506)\end{array}$ & $\begin{array}{c}57.079 \\
(47.469)\end{array}$ & $\begin{array}{l}5.971 \text { ** } \\
(2.665)\end{array}$ \\
\hline & 430 & 796 & \\
\hline \multirow[t]{3}{*}{ Clerks } & 47.662 & 49.537 & -1.876 \\
\hline & $(27.173)$ & $(67.920)$ & $(2.453)$ \\
\hline & 814 & 2,103 & \\
\hline \multirow[t]{2}{*}{ Service workers } & $\begin{array}{c}49.199 \\
(32.535)\end{array}$ & $\begin{array}{c}28.898 \\
(85.561)\end{array}$ & $\begin{array}{l}20.301^{* * *} \\
(3.405)\end{array}$ \\
\hline & 648 & 3,557 & \\
\hline \multirow[t]{3}{*}{ Agriculture workers } & 32.042 & 23.220 & 8.822 \\
\hline & $(15.821)$ & $(13.766)$ & $(6.962)$ \\
\hline & 4 & 216 & \\
\hline \multirow[t]{3}{*}{ Craft workers } & 39.137 & 35.007 & $4.13^{* *}$ \\
\hline & $(25.641)$ & $(18.062)$ & $(1.835)$ \\
\hline & 102 & 3,862 & \\
\hline \multirow[t]{3}{*}{ Operators } & 37.397 & 37.844 & -0.446 \\
\hline & $(17.460)$ & $(29.996)$ & $(2.494)$ \\
\hline & 149 & 1,719 & \\
\hline \multirow[t]{3}{*}{ Unskilled workers } & 29.943 & 23.174 & $6.77^{\star \star \star *}$ \\
\hline & (14.291) & $(14.751)$ & $(0.643)$ \\
\hline & 555 & 9,823 & \\
\hline \multirow[t]{3}{*}{ Unclassified workers } & 38.413 & 31.347 & 7.066 \\
\hline & (33.011) & $(23.124)$ & (8.738) \\
\hline & 10 & 46 & \\
\hline \multicolumn{4}{|c|}{ Notes: } \\
\hline \multicolumn{4}{|c|}{ 1. Standard errors are in parentheses. } \\
\hline \multicolumn{4}{|c|}{ 2. No. of observations are indicated below the standard errors. } \\
\hline \multicolumn{4}{|c|}{ 3. Statistical significance is indicated by $* * *(\alpha=1 \%),{ }^{* *}(\alpha=5 \%),{ }^{*}(\alpha=10 \%)$. } \\
\hline
\end{tabular}


Table 2. Demographics by sector

\begin{tabular}{|c|c|c|c|}
\hline & $\begin{array}{c}\text { Public } \\
\text { (1) }\end{array}$ & $\begin{array}{c}\text { Private } \\
\text { (2) }\end{array}$ & $\begin{array}{c}\text { Difference } \\
\text { (Public-Private) } \\
\text { (3) }\end{array}$ \\
\hline Age & $\begin{array}{c}42.465 \\
6,211\end{array}$ & $\begin{array}{l}35.010 \\
27,787\end{array}$ & $7.455^{\star \star \star *}$ \\
\hline$\%$ Male & $\begin{array}{c}48.559 \\
(49.983)\end{array}$ & $\begin{array}{c}71.537 \\
(48.036)\end{array}$ & $\begin{array}{l}-22.978^{* * *} \\
(0.646)\end{array}$ \\
\hline$\%$ Female & $\begin{array}{c}51.441 \\
(49.983)\end{array}$ & $\begin{array}{c}28.463 \\
(45.125)\end{array}$ & $\begin{array}{l}22.978^{\star \star \star \star} \\
(0.646)\end{array}$ \\
\hline$\%$ Single & $\begin{array}{c}18.628 \\
(38.937)\end{array}$ & $\begin{array}{c}36.121 \\
(48.036)\end{array}$ & $\begin{array}{l}-17.493^{\star \star \star \star} \\
(0.653)\end{array}$ \\
\hline$\%$ Married & $\begin{array}{c}74.561 \\
(43.555)\end{array}$ & $\begin{array}{c}58.984 \\
(49.187)\end{array}$ & $\begin{array}{l}15.5777^{\star * \star *} \\
(0.677)\end{array}$ \\
\hline$\%$ Widowed & $\begin{array}{c}4.878 \\
(21.543)\end{array}$ & $\begin{array}{c}2.717 \\
(16.258)\end{array}$ & $\begin{array}{l}2.161 \text { *** } \\
(0.243)\end{array}$ \\
\hline$\%$ Separated & $\begin{array}{c}1.932 \\
(13.766)\end{array}$ & $\begin{array}{c}2.134 \\
(14.452)\end{array}$ & $\begin{array}{l}-0.202 \\
(0.201)\end{array}$ \\
\hline Family size & $\begin{array}{c}5.267 \\
(2.153)\end{array}$ & $\begin{array}{c}5.517 \\
(2.271)\end{array}$ & $\begin{array}{l}-0.250^{\star * \star *} \\
(3.158)\end{array}$ \\
\hline$\%$ College graduates & $\begin{array}{c}55.080 \\
(49.745)\end{array}$ & $\begin{array}{c}14.903 \\
(35.612)\end{array}$ & $\begin{array}{l}40.177^{\star \star \star \star} \\
(0.542)\end{array}$ \\
\hline No. of observations & 6,211 & 27,787 & \\
\hline $\begin{array}{l}\text { Notes: } \\
\text { 1. Standard errors are in } \\
\text { 2. Statistical significance }\end{array}$ & $\begin{array}{l}\text { rentheses. } \\
\text { indicated by }\end{array}$ & $(\alpha=1 \%),{ }^{* *}$ & $5 \%),{ }^{*}(\alpha=10 \%)$ \\
\hline
\end{tabular}

Table 3. Cross-correlations between hourly wages and demographic factors

\begin{tabular}{|lc|}
\multicolumn{1}{l}{} & Hourly wage \\
\hline Age & 0.1143 \\
Male & -0.0602 \\
Female & 0.0602 \\
Single & -0.0673 \\
Married & 0.0643 \\
Widowed & -0.0008 \\
Separated & 0.0053 \\
Family size & -0.0198 \\
College graduate & 0.3253 \\
\hline
\end{tabular}

Source: Merged LFS and FIES 2009. Author's estimates. 
Table 4. OLS estimates of public-private wage differential by occupation group

\begin{tabular}{|c|c|c|}
\hline $\begin{array}{c}\text { Dependent variable } \\
\text { In(hourly wage) }\end{array}$ & $\begin{array}{l}\text { Without region FE } \\
\text { (1) }\end{array}$ & $\begin{array}{l}\text { With region FE } \\
(2)\end{array}$ \\
\hline \multirow[t]{3}{*}{ Leaders } & $0.209^{* * *}$ & $0.336^{* \star *}$ \\
\hline & $(0.042)$ & $(0.040)$ \\
\hline & 0.000 & 0.000 \\
\hline \multirow[t]{3}{*}{ Professionals } & $0.148^{\star * \star}$ & $0.275^{\star \star \star *}$ \\
\hline & $(0.022)$ & $(0.022)$ \\
\hline & 0.000 & 0.000 \\
\hline \multirow[t]{3}{*}{ Associates } & -0.039 & 0.058 \\
\hline & $(0.038)$ & $(0.036)$ \\
\hline & 0.304 & 0.113 \\
\hline \multirow[t]{3}{*}{ Clerks } & $-0.143^{\star * *}$ & -0.018 \\
\hline & $(0.023)$ & $(0.021)$ \\
\hline & 0.000 & 0.411 \\
\hline \multirow[t]{3}{*}{ Service workers } & $0.224^{\star * *}$ & $0.254^{\star * *}$ \\
\hline & $(0.030)$ & $(0.030)$ \\
\hline & 0.000 & 0.000 \\
\hline \multirow[t]{3}{*}{ Agriculture workers } & 0.182 & 0.139 \\
\hline & $(0.117)$ & $(0.159)$ \\
\hline & 0.121 & 0.382 \\
\hline \multirow[t]{3}{*}{ Craft workers } & -0.039 & 0.058 \\
\hline & $(0.058)$ & $(0.053)$ \\
\hline & 0.494 & 0.271 \\
\hline \multirow[t]{3}{*}{ Unskilled workers } & $0.159^{* * *}$ & $0.113^{\star * *}$ \\
\hline & $(0.024)$ & $(0.024)$ \\
\hline & 0.000 & 0.000 \\
\hline \multirow[t]{3}{*}{ Unclassified workers } & -0.023 & -0.010 \\
\hline & $(0.237)$ & $(0.236)$ \\
\hline & 0.922 & 0.967 \\
\hline Demographics & Yes & Yes \\
\hline Skill level & Yes & Yes \\
\hline Skill types & Yes & Yes \\
\hline Occupation fixed effects & Yes & Yes \\
\hline Region fixed effects & No & Yes \\
\hline Constant & Yes & Yes \\
\hline No. of observations & 29,133 & 29,133 \\
\hline Adj. R-squared & 0.431 & 0.504 \\
\hline \multicolumn{3}{|c|}{ Notes: } \\
\hline \multicolumn{3}{|c|}{ 1. Statistical significance is indicated by ${ }^{* * *}(\alpha=1 \%),{ }^{* *}(\alpha=5 \%),{ }^{*}(\alpha=10 \%)$. } \\
\hline \multicolumn{3}{|c|}{ 2. Heteroskedasticity-robust standard errors are in parentheses. } \\
\hline \multicolumn{3}{|c|}{ 3. P-values are reported below the standard errors. } \\
\hline \multicolumn{3}{|c|}{ 4. Reference occupation group: Operators } \\
\hline
\end{tabular}


Table 5. Consumption per capita in $\mathbf{2 0 0 9}$, by region

\begin{tabular}{lc}
\hline Region & Regional Average / National Average \\
\hline & \\
National Capital Region & $186 \%$ \\
Cordillera Administrative Region & $96 \%$ \\
llocos & $91 \%$ \\
Cagayan & $83 \%$ \\
Central Luzon & $107 \%$ \\
CALABARZON & $118 \%$ \\
MIMAROPA & $74 \%$ \\
Bicol & $75 \%$ \\
Western Visayas & $83 \%$ \\
Central Visayas & $84 \%$ \\
Eastern Visayas & $77 \%$ \\
Zamboanga & $64 \%$ \\
Northern Mindanao & $75 \%$ \\
Davao & $80 \%$ \\
SOCCSKSARGEN & $76 \%$ \\
CARAGA & $65 \%$ \\
ARMM & $46 \%$ \\
\end{tabular}

Source: National Statisical Coordination Board 
Table 6. Geographic distribution of associates, clerks and craft workers (\% distribution by region)

\begin{tabular}{|l|cc|cc|cc|}
\hline \multirow{2}{*}{ Region } & \multicolumn{2}{|c|}{ Associates } & \multicolumn{2}{c|}{ Clerks } & \multicolumn{2}{c|}{ Craft Workers } \\
\cline { 2 - 7 } & Public & Private & Public & Private & Public & Private \\
National Capital Region & 8.69 & 28.31 & 13.57 & 31.52 & 12.15 & 17.60 \\
CAR & 5.11 & 3.84 & 5.21 & 2.22 & 3.74 & 3.60 \\
Ilocos & 4.77 & 4.55 & 3.91 & 3.60 & 5.61 & 5.19 \\
Cagayan & 3.92 & 2.83 & 4.45 & 2.05 & 4.67 & 3.04 \\
Central Luzon & 6.13 & 6.47 & 6.84 & 10.84 & 4.67 & 12.39 \\
CALABARZON & 7.33 & 15.27 & 5.97 & 13.73 & 3.74 & 14.34 \\
MIMAROPA & 4.77 & 1.92 & 5.86 & 1.80 & 2.80 & 2.79 \\
Bicol & 6.64 & 2.63 & 5.75 & 3.06 & 4.67 & 5.14 \\
Western Visayas & 6.64 & 4.65 & 6.19 & 5.36 & 11.21 & 4.99 \\
Central Visayas & 7.33 & 8.29 & 5.86 & 7.58 & 8.41 & 10.23 \\
Eastern Visayas & 5.96 & 2.83 & 5.54 & 2.60 & 8.41 & 2.63 \\
Zamboanga & 4.26 & 2.02 & 4.89 & 2.09 & 4.67 & 3.17 \\
Northern Mindanao & 4.60 & 3.13 & 7.06 & 3.64 & 8.41 & 4.00 \\
Davao & 8.69 & 5.97 & 3.69 & 4.81 & 5.61 & 4.15 \\
SOCCSKSARGEN & 7.50 & 3.34 & 4.78 & 2.60 & 1.87 & 3.17 \\
CARAGA & 7.33 & 2.33 & 6.73 & 2.01 & 8.41 & 3.27 \\
ARMM & 0.34 & 1.62 & 3.69 & 0.50 & 0.93 & 0.30 \\
& & & & & & \\
\hline
\end{tabular}

Source: LFS and FIES, National Statistics Office 
Table 7. OLS estimates of public-private wage differential, richer regions and poorer regions

\begin{tabular}{|c|c|c|}
\hline $\begin{array}{l}\text { Dependent variable } \\
\text { In(hourly wage) }\end{array}$ & $\begin{array}{c}\text { Richer regions } \\
\text { (1) }\end{array}$ & $\begin{array}{c}\text { Poorer regions } \\
(2)\end{array}$ \\
\hline \multirow[t]{3}{*}{ Leaders } & $0.253^{\star * \star}$ & 0.239 *** \\
\hline & $(0.051)$ & $(0.076)$ \\
\hline & 0.000 & 0.002 \\
\hline \multirow[t]{3}{*}{ Professionals } & $0.091 * * *$ & $0.444^{\star * \star}$ \\
\hline & $(0.026)$ & $(0.044)$ \\
\hline & 0.000 & 0.000 \\
\hline \multirow[t]{3}{*}{ Associates } & $-0.087^{* *}$ & $0.302^{* * *}$ \\
\hline & $(0.043)$ & $(0.077)$ \\
\hline & 0.045 & 0.000 \\
\hline \multirow[t]{3}{*}{ Clerks } & $-0.106^{\star \star \star \star}$ & 0.070 * \\
\hline & $(0.028)$ & $(0.038)$ \\
\hline & 0.000 & 0.071 \\
\hline \multirow[t]{3}{*}{ Service workers } & $0.149^{\star * \star}$ & $0.530^{* \star *}$ \\
\hline & $(0.036)$ & $(0.052)$ \\
\hline & 0.000 & 0.000 \\
\hline \multirow[t]{3}{*}{ Agriculture workers } & 0.004 & $0.534^{\star \star \star}$ \\
\hline & $(0.114)$ & $(0.095)$ \\
\hline & 0.972 & 0.000 \\
\hline \multirow[t]{3}{*}{ Craft workers } & 0.015 & -0.045 \\
\hline & $(0.064)$ & $(0.106)$ \\
\hline & 0.810 & 0.672 \\
\hline \multirow[t]{3}{*}{ Unskilled workers } & $0.152^{\star * \star *}$ & $0.154^{\star \star *}$ \\
\hline & $(0.030)$ & $(0.040)$ \\
\hline & 0.000 & 0.000 \\
\hline \multirow[t]{3}{*}{ Unclassified workers } & -0.159 & 0.512 \\
\hline & $(0.348)$ & $(0.316)$ \\
\hline & 0.647 & 0.106 \\
\hline Demographics & Yes & Yes \\
\hline Skill level & Yes & Yes \\
\hline Skill types & Yes & Yes \\
\hline Occupation fixed effects & Yes & Yes \\
\hline Constant & Yes & Yes \\
\hline No. of observations & 20,273 & 8,860 \\
\hline Adj. R-squared & 0.429 & 0.466 \\
\hline \multicolumn{3}{|c|}{ Notes: } \\
\hline \multirow{2}{*}{\multicolumn{3}{|c|}{$\begin{array}{l}\text { 1. Statistical significance is indicated by }{ }^{* * *}(\alpha=1 \%),{ }^{* *}(\alpha=5 \%),{ }^{*}(\alpha=10 \%) \text {. } \\
\text { 2. Heteroskedasticity-robust standard errors are in parentheses. }\end{array}$}} \\
\hline & & eses. \\
\hline \multicolumn{3}{|c|}{ 3. P-values are reported below the standard errors. } \\
\hline \multicolumn{3}{|c|}{ 4. Reference occupation group: Operators } \\
\hline
\end{tabular}


Table 8. OLS estimates of public-private wage gap by gender

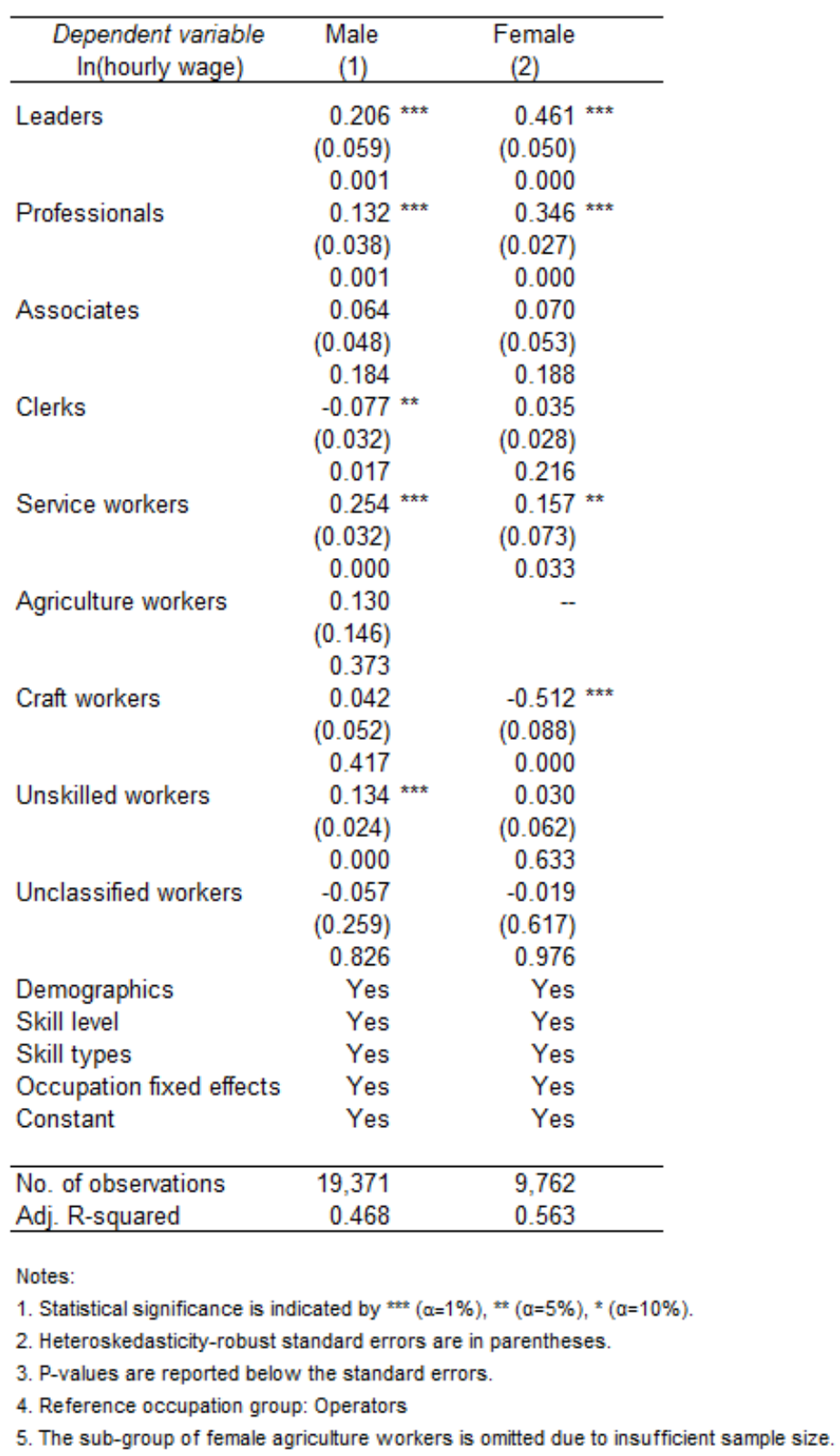




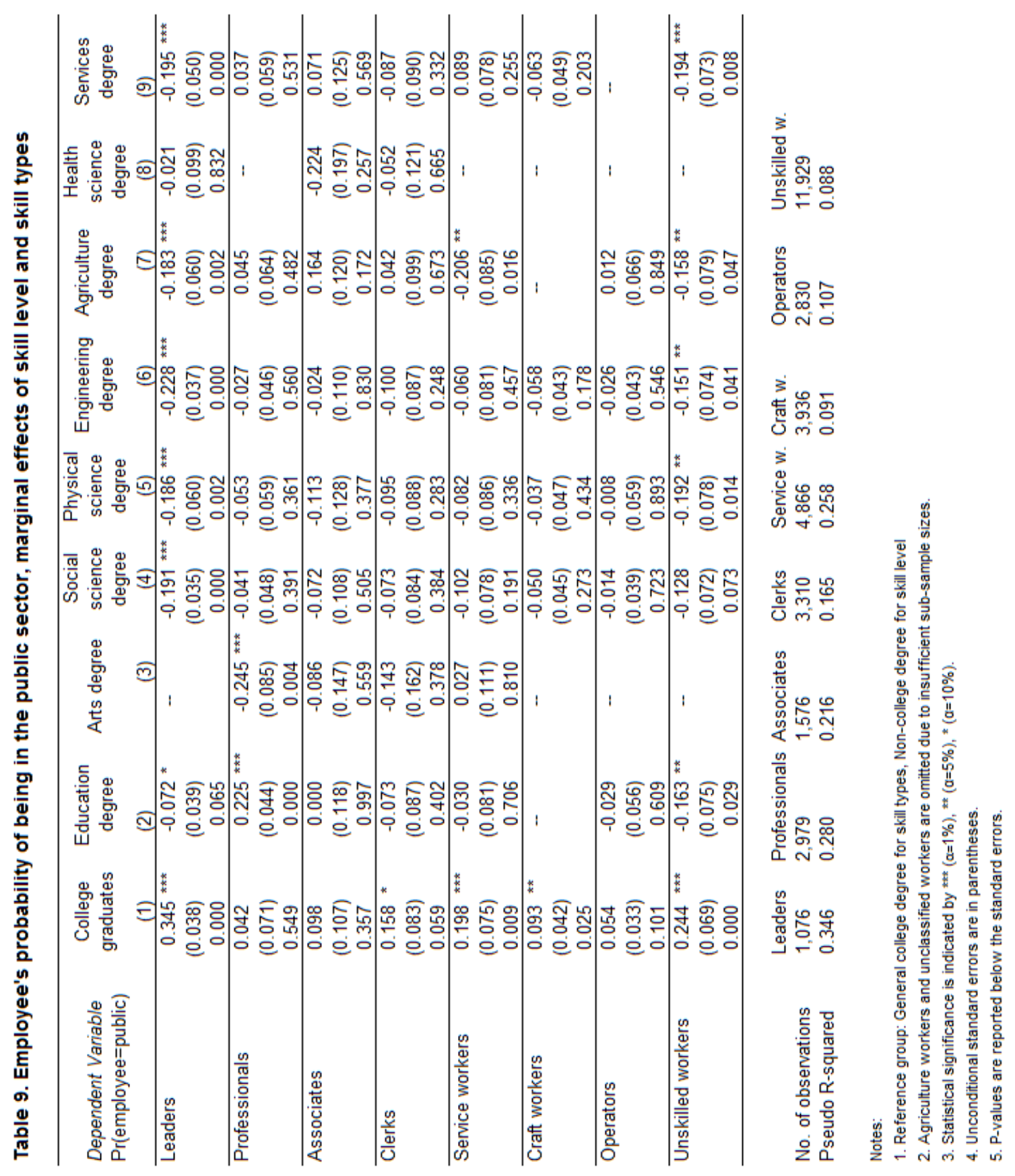


Table 10. OLS estimates of difference in no. of hours worked between public and private employees

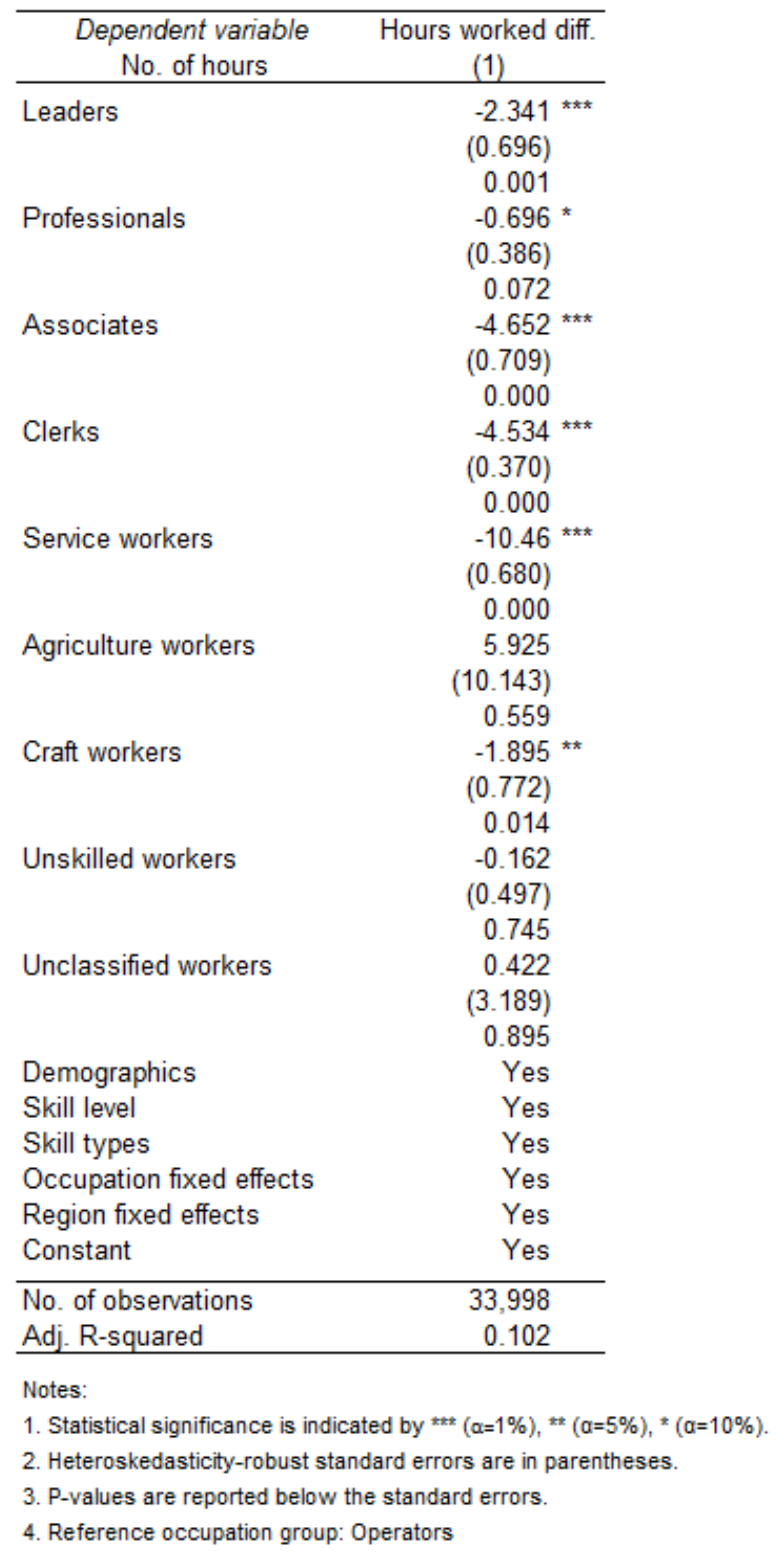


Table 11. OLs estimates of differentials in giving behaviour between public and private employees

\begin{tabular}{|c|c|c|c|}
\hline $\begin{array}{c}\text { Dependent variable } \\
\ln \text { (gifts) }\end{array}$ & $\begin{array}{l}\text { Gifts given } \\
\text { (1) }\end{array}$ & $\begin{array}{l}\text { Gifts received } \\
\text { (2) }\end{array}$ & $\begin{array}{l}\text { Net gifts given } \\
\text { (3) }\end{array}$ \\
\hline \multirow[t]{3}{*}{ Leaders } & $0.465^{\star * *}$ & 0.048 & 0.248 \\
\hline & $(0.119)$ & $(0.144)$ & $(0.162)$ \\
\hline & 0.000 & 0.738 & 0.126 \\
\hline \multirow[t]{3}{*}{ Professionals } & $0.256^{\star \star \star *}$ & -0.031 & 0.070 \\
\hline & $(0.063)$ & $(0.079)$ & $(0.087)$ \\
\hline & 0.000 & 0.698 & 0.419 \\
\hline \multirow[t]{3}{*}{ Associates } & $0.303^{\star * *}$ & -0.070 & 0.238 * \\
\hline & $(0.094)$ & $(0.110)$ & $(0.143)$ \\
\hline & 0.001 & 0.521 & 0.096 \\
\hline \multirow[t]{3}{*}{ Clerks } & $0.147^{* *}$ & 0.106 & $0.266^{* *}$ \\
\hline & $(0.067)$ & $(0.076)$ & $(0.106)$ \\
\hline & 0.027 & 0.163 & 0.012 \\
\hline \multirow[t]{3}{*}{ Service workers } & $0.250^{\star \star *}$ & -0.132 * & 0.024 \\
\hline & $(0.074)$ & $(0.077)$ & $(0.120)$ \\
\hline & 0.001 & 0.086 & 0.845 \\
\hline \multirow[t]{3}{*}{ Agriculture workers } & 0.482 & $-1.008^{*}$ & -0.945 \\
\hline & $(0.568)$ & $(0.606)$ & $(0.854)$ \\
\hline & 0.396 & 0.096 & 0.268 \\
\hline \multirow[t]{3}{*}{ Craft workers } & $0.299 * *$ & 0.181 & -0.267 \\
\hline & $(0.138)$ & $(0.155)$ & $(0.368)$ \\
\hline & 0.030 & 0.242 & 0.468 \\
\hline \multirow[t]{3}{*}{ Unskilled workers } & $0.406^{* \star *}$ & $0.137^{* *}$ & $0.218^{*}$ \\
\hline & $(0.069)$ & $(0.068)$ & $(0.127)$ \\
\hline & 0.000 & 0.044 & 0.085 \\
\hline \multirow[t]{3}{*}{ Unclassified workers } & $1.581^{\star * *}$ & $-1.013^{*}$ & 1.481 \\
\hline & $(0.559)$ & $(0.520)$ & $(0.940)$ \\
\hline & 0.005 & 0.051 & 0.115 \\
\hline Hourly wage rate & Yes & Yes & Yes \\
\hline Demographics & Yes & Yes & Yes \\
\hline Skill level & Yes & Yes & Yes \\
\hline Skill types & Yes & Yes & Yes \\
\hline Occupation fixed effects & Yes & Yes & Yes \\
\hline Region fixed effects & Yes & Yes & Yes \\
\hline Constant & Yes & Yes & Yes \\
\hline No. of observations & 24,479 & 25,079 & 9,849 \\
\hline Adj. R-squared & 0.321 & 0.046 & 0.210 \\
\hline \multicolumn{4}{|l|}{ Notes: } \\
\hline \multicolumn{4}{|c|}{ 1. Statistical significance is indicated by ${ }^{* *}(\alpha=1 \%),{ }^{* *}(\alpha=5 \%),{ }^{*}(\alpha=10 \%)$. } \\
\hline \multicolumn{4}{|c|}{ 2. Heteroskedasticity-robust standard errors are in parentheses. } \\
\hline \multicolumn{4}{|c|}{ 3. P-values are reported below the standard errors. } \\
\hline \multicolumn{4}{|c|}{ 4. Reference occupation group: Operators } \\
\hline
\end{tabular}


Table 12. OLS estimates of differentials in risk-taking behaviour between public and private employees

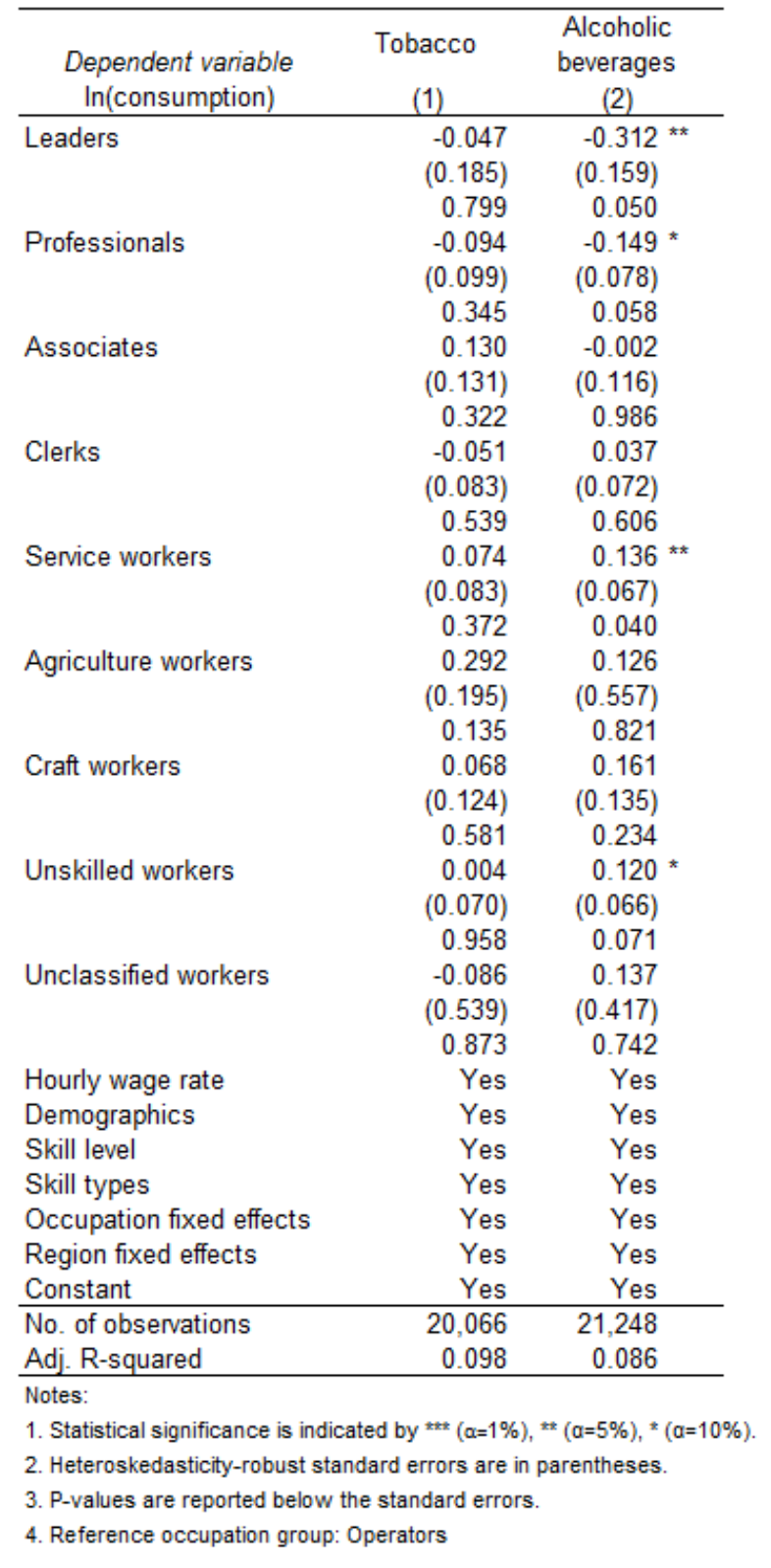


Table 13. OLS estimates of public-private wage differential by occupation group, full sample vs. occupation group sub-samples

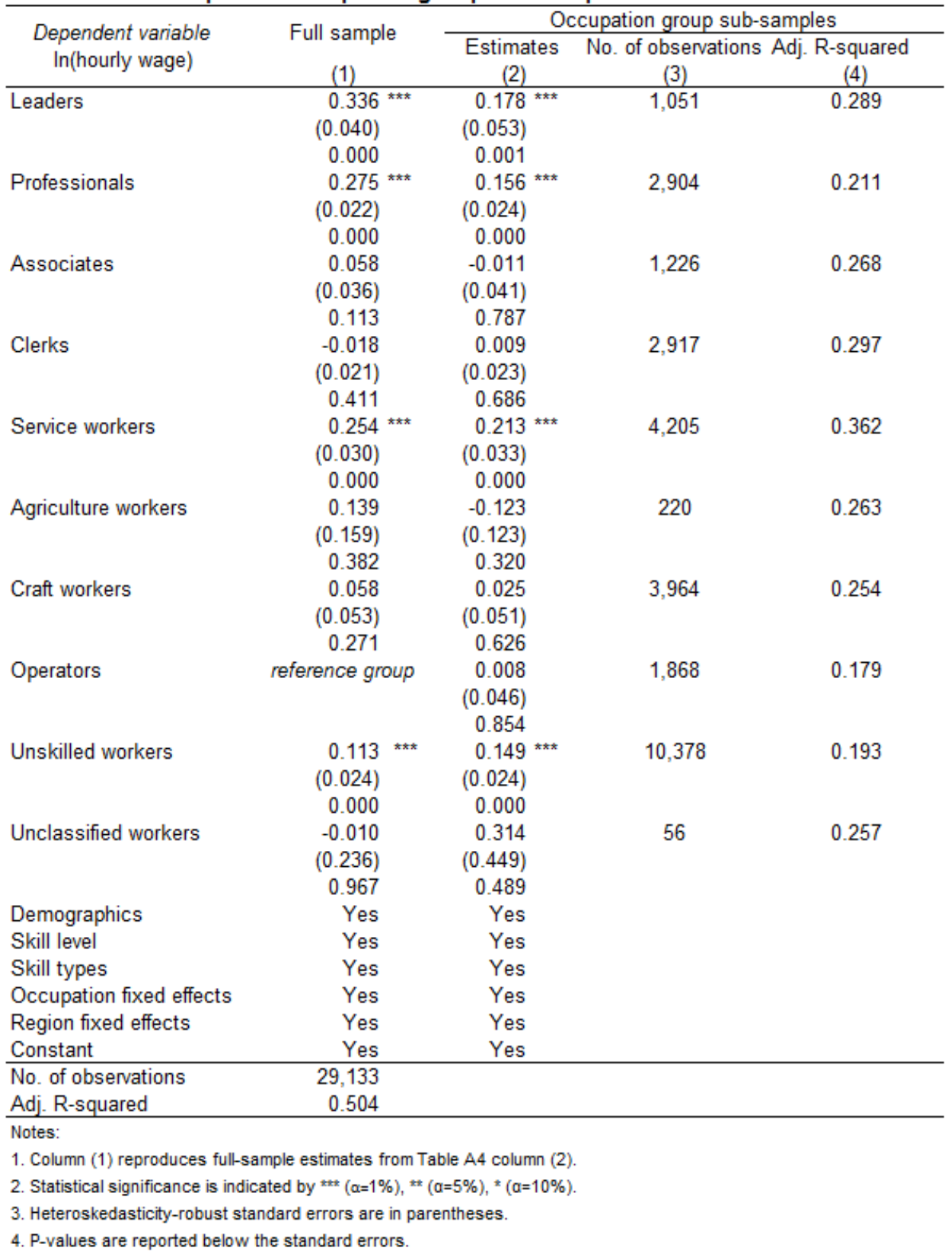


Table 14. PSM estimates of public-private wage differential, by occupation group sub-samples

\begin{tabular}{|c|c|c|c|c|c|}
\hline \multirow{4}{*}{$\begin{array}{c}\text { Outcome variable } \\
\text { In(hourly wage) }\end{array}$} & \multicolumn{4}{|c|}{ Propensity score matching } & \multirow{4}{*}{$\begin{array}{c}\text { Estimates } \\
\text { Average treatment } \\
\text { effect on the treated } \\
\text { (ATT) } \\
\text { (5) }\end{array}$} \\
\hline & \multirow{3}{*}{$\begin{array}{c}\text { Standardized } \\
\text { bias, means } \\
\text { (1) }\end{array}$} & \multirow{3}{*}{$\begin{array}{l}\text { Pseudo } \\
\text { R-sq. } \\
\text { (2) }\end{array}$} & \multicolumn{2}{|c|}{$\begin{array}{c}\text { No. of observations on } \\
\text { common support }\end{array}$} & \\
\hline & & & Treated & Untreated & \\
\hline & & & (3) & (4) & \\
\hline Leaders & $\begin{array}{l}7.440 \\
(5.85)\end{array}$ & 0.373 & 201 & 834 & N.A. \\
\hline Professionals & $\begin{array}{c}3.371 \\
(3.736)\end{array}$ & 0.286 & 1,760 & 1,123 & $\begin{array}{l}0.285^{\star \star \star} \\
(0.045)\end{array}$ \\
\hline Associates & $\begin{array}{c}4.411 \\
(4.155)\end{array}$ & 0.238 & 424 & 796 & $\begin{array}{r}0.053 \\
(0.060)\end{array}$ \\
\hline Clerks & $\begin{array}{l}2.293 \\
(2.091)\end{array}$ & 0.199 & 789 & 2,103 & $\begin{array}{l}0.082^{* \star *} \\
(0.031)\end{array}$ \\
\hline Service workers & $\begin{array}{l}3.668 \\
(3.230)\end{array}$ & 0.300 & 637 & 3,550 & $\begin{array}{l}0.303^{* * *} \\
(0.044)\end{array}$ \\
\hline Agriculture workers & $\begin{array}{c}8.336 \\
(24.047)\end{array}$ & 0.251 & 3 & 41 & N.A. \\
\hline Craft workers & $\begin{array}{l}3.862 \\
(3.613)\end{array}$ & 0.090 & 102 & 3,747 & $\begin{array}{r}0.004 \\
(0.063)\end{array}$ \\
\hline Operators & $\begin{array}{c}3.739 \\
(2.620)\end{array}$ & 0.125 & 149 & 1,681 & $\begin{array}{l}(0.030) \\
(0.051)\end{array}$ \\
\hline Unskilled workers & $\begin{array}{l}2.266 \\
(1.659)\end{array}$ & 0.084 & 554 & 9,820 & $\begin{array}{l}0.154^{\star \star *} \\
(0.026)\end{array}$ \\
\hline Unclassified workers & N.A. & & & & N.A. \\
\hline
\end{tabular}

Notes:

1. Column (1) indicates match quality of propensity scores based on standardized bias. As a rule of thumb, I did not report ATT estimates when the standardized bias is above $5 \%$ (Caliendo and Kopeinig, 2008) because ATT estimates cannot be considered valid when propensity score matching was not sufficiently achieved.

2. Column (2) indicates match quality based on the Pseudo R-squared. Low values indicate good match quality.

3. I used the nearest 5 neighbors with replacement for the matching algorithm.

4. Treated group refers to public employees; Untreated group refers to private employees

5. Statistical significance is indicated by ${ }^{* * *}(\alpha=1 \%),{ }^{* *}(\alpha=5 \%),{ }^{*}(\alpha=10 \%)$.

6. Standard errors are in parentheses. 


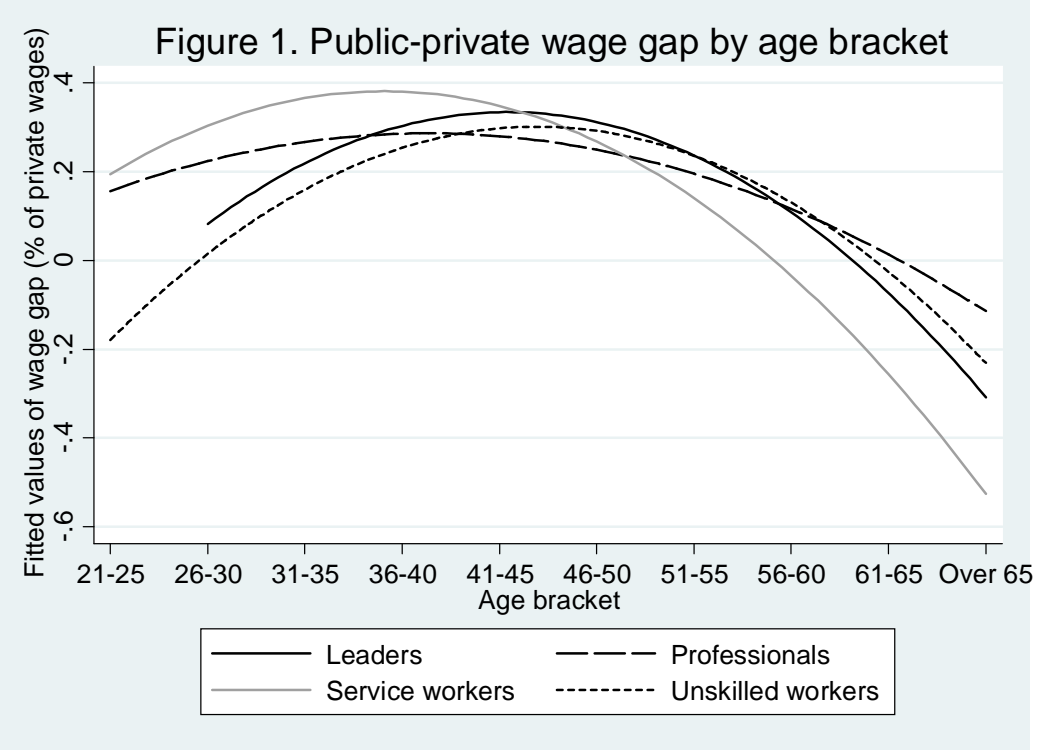

Figure 2. Public-private wage gap and effort gap

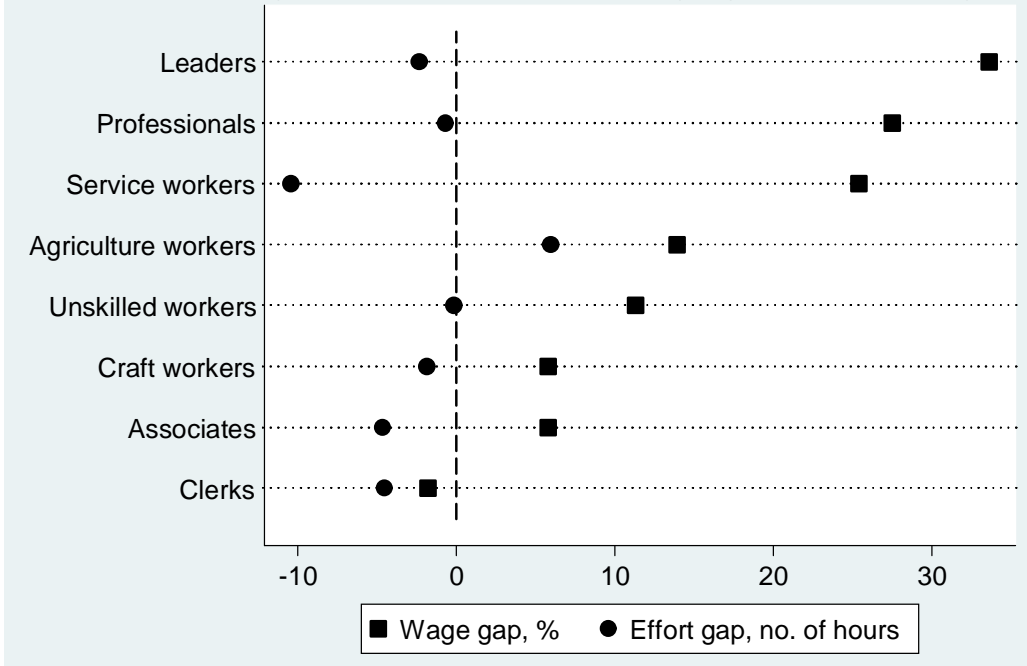




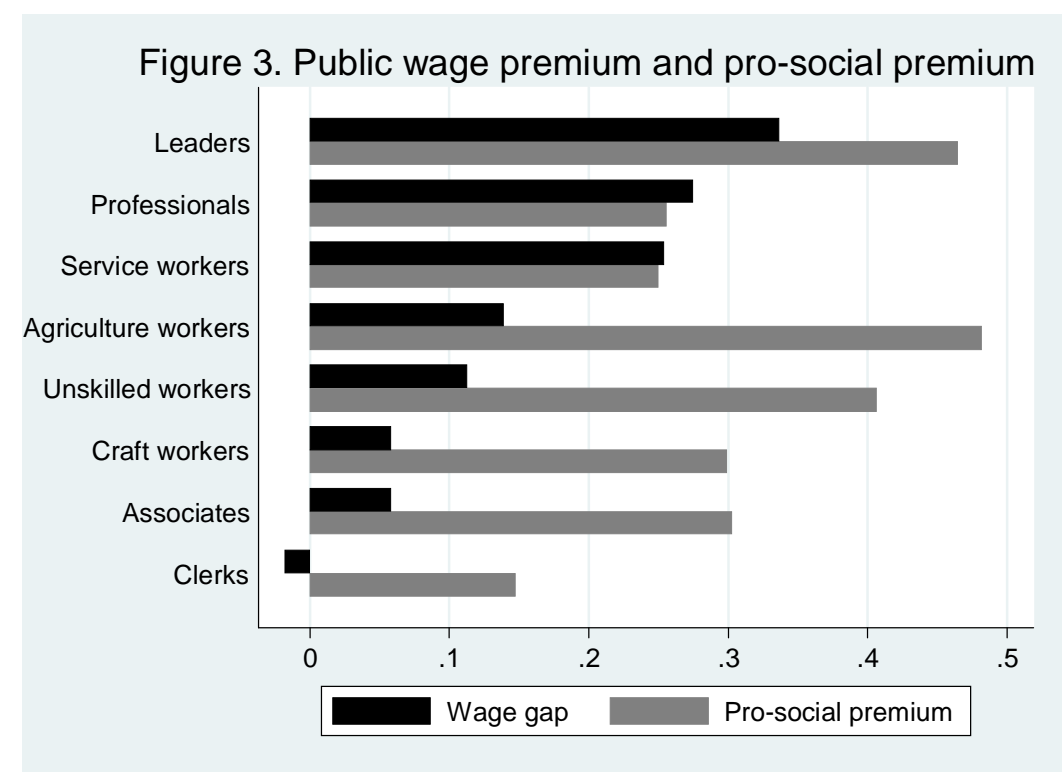

Figure 4. Public-private wage gap and risk aversion gap

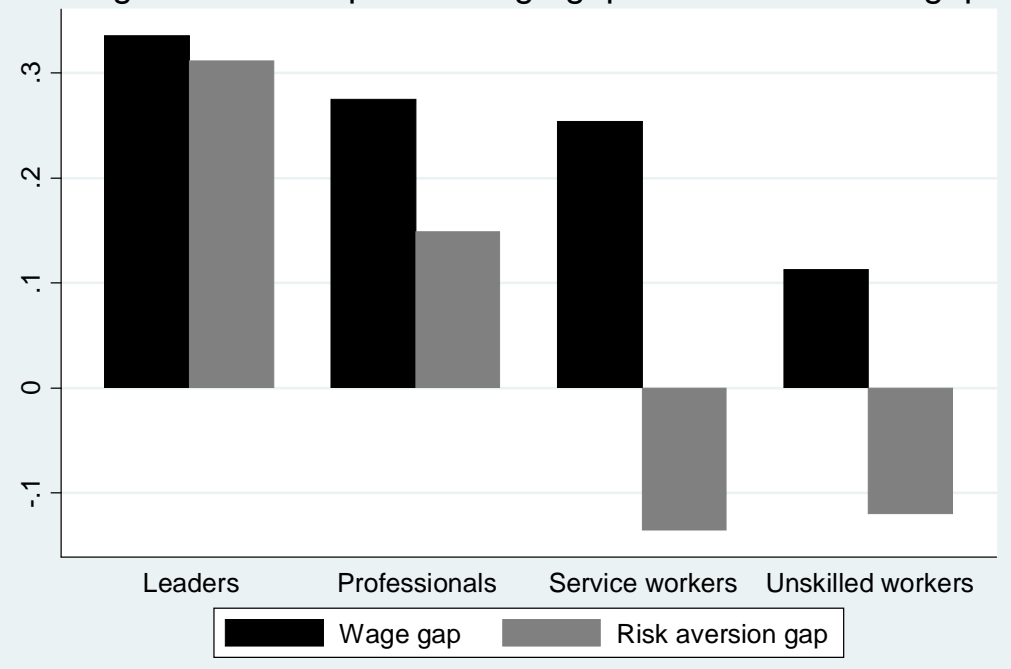




\section{References}

[1] Adamchik, V. A., \& Bedi, A. S. (2000). Wage differentials between the public and the private sectors: Evidence from an economy in transition. Labour economics, 7(2), 203-224.

[2] Bellante, D., \& Link, A. N. (1981). Are public sector workers more risk averse than private sector workers?. Industrial and Labor Relations Review, 408-412.

[3] Buurman, M., Delfgaauw, J., Dur, R., \& Van den Bossche, S. (2012). Public sector employees: Risk averse and altruistic?. Journal of Economic Behavior \& Organization, 83(3), 279-291.

[4] Buurman, M., \& Dur, R. (2012). Incentives and the Sorting of Altruistic Agents into Street-Level Bureaucracies*. The Scandinavian Journal of Economics, 114(4), 1318-1345.

[5] Caliendo, M., \& Kopeinig, S. (2008). Some practical guidance for the implementation of propensity score matching. Journal of economic surveys, 22(1), 31-72.

[6] de Castro, F., Salto, M., \& Steiner, H. (2013). The gap between public and private wages: new evidence for the EU (No. 508). Directorate General Economic and Monetary Affairs (DG ECFIN), European Commission.

[7] Depalo, D., Pereira, M. C., Eugène, B., Papapetrou, E., Perez, J. J., Reiss, L., \& Roter, M. (2011). The public sector pay gap in a selection of Euro area countries (No. 1406). European Central Bank.

[8] Disney, R., \& Gosling, A. (1998). Does it pay to work in the public sector?. Fiscal Studies, 19(4), 347-374.

[9] Dur, R., \& Zoutenbier, R. (2013). Intrinsic motivations of public sector employees: Evidence for Germany (No. 623). SOEPpapers on Multidisciplinary Panel Data Research. 
[10] Francois, P. (2000). 'Public service motivation'as an argument for government provision. Journal of Public Economics, 78(3), 275-299.

[11] Francois, P., \& Vlassopoulos, M. (2008). Pro-social motivation and the delivery of social services. CESifo Economic Studies, 54(1), 22-54.

[12] Gorodnichenko, Y., \& Sabirianova Peter, K. (2007). Public sector pay and corruption: Measuring bribery from micro data. Journal of Public economics, 91(5), 963-991.

[13] Gregg, P., Grout, P. A., Ratcliffe, A., Smith, S., \& Windmeijer, F. (2011). How important is pro-social behaviour in the delivery of public services?. Journal of public economics, 95(7), 758-766.

[14] Gregory, R. G., \& Borland, J. (1999). Recent developments in public sector labor markets. Handbook of labor economics, 3, 3573-3630.

[15] Krueger, A. B. (1988). Are public sector workers paid more than their alternative wage? Evidence from longitudinal data and job queues. In When public sector workers unionize (pp. 217-242). University of Chicago Press.

[16] Mueller, R. E. (1998). Public-private sector wage differentials in Canada: evidence from quantile regressions. Economics Letters, 60(2), 229-235.

[17] Mueller, R. E. (2000). Public-and Private-Sector Wage Differentials in Canada Revisited. Industrial Relations: A Journal of Economy and Society, 39(3), 375-400.

[18] Panizza, U., di Tella, R., \& Van Rijckeghem, C. (2001). Public Sector Wages and Bureaucratic Quality: Evidence from Latin America [with Comments]. Economía, 97-151.

[19] Poterba, J. M., \& Rueben, K. S. (1994). The distribution of public sector wage premia: new evidence using quantile regression methods (No. w4734). National Bureau of Economic Research. 
[20] Sakellariou, C. (2004). The use of quantile regressions in estimating gender wage differentials: a case study of the Philippines. Applied Economics, 36(9), 1001-1007. 